\title{
The Growing Link Between the Federal Government and State and Local Government Financing
}

\author{
NANCY AMMON JIANAKOPLOS
}

Fivin

HE growth of the state and local government sector and its increasing reliance on Federal revenues warrant consideration in discussions of stabilization policy. State and local government expenditures and taxes have been growing rapidly in recent decades, both absolutely and relative to that at the Federal level. In addition, grants-in"aid from the Federal Government have become an increasingly important source of funds for state and local governments.

Concern about stabilization policy has been focused primarily on monetary and fiscal policies of the Federal Government. Many analysts would agree that this focus on Federal policy is not misplaced since stabilization policy is not a major responsibility of state and local governments. ${ }^{1}$ Whether or not one believes that state and local governments can or should actively pursue policies to affect national income, state and local government spending and taxing decisions do in fact constitute a part of total government fiscal policy. State and local fiscal activities do influence economic activity, although there remains some controversy over the nature, degree, and duration of these effects.

A full evaluation of government stabilization policy requires consideration of the impact of the state and

The rationale behind this distribution of government functions among levels of government is discussed by Richard A. Musgrave and Peggy B. Musgrave, Public Finance in Theory and Practice (New York: MoGraw-Hill Book Company, 1973), Chapter 26, pp. 595-621. local sector on aggregate economic activity. Do state and local policies reinforce or compete with Federal policies? Is the financing of state and local government spending carried out under different constraints than at the Federal level? Has the increasing reliance on Federal aid altered the character of state and local government financing?

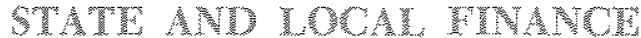

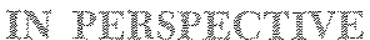

\section{Capenditures}

A more detailed examination of the data on government expenditures gives a perspective on the relative size of and functions performed by the different levels of government. Since 1960, state and local expenditures on a national income accounts (NIA basis have increased at an average annual rate of 10.5 percent, compared to a 9.3 percent rate of increase in Federal expenditures. Purchases of goods and services accounted for 94 percent of state and local expenditures in 1976, compared to 34 percent at the Federal level (Table I). These expenditures represent the purchase of goods and services by the public sector and are the government component of GNP. Currently, state and local purchases represent 14 percent of GNP, compared to 8 percent represented by Federal purchases.

Other expenditures by government determine not so much what goods will be produced, but rather who will decide what goods to produce. In particular, 


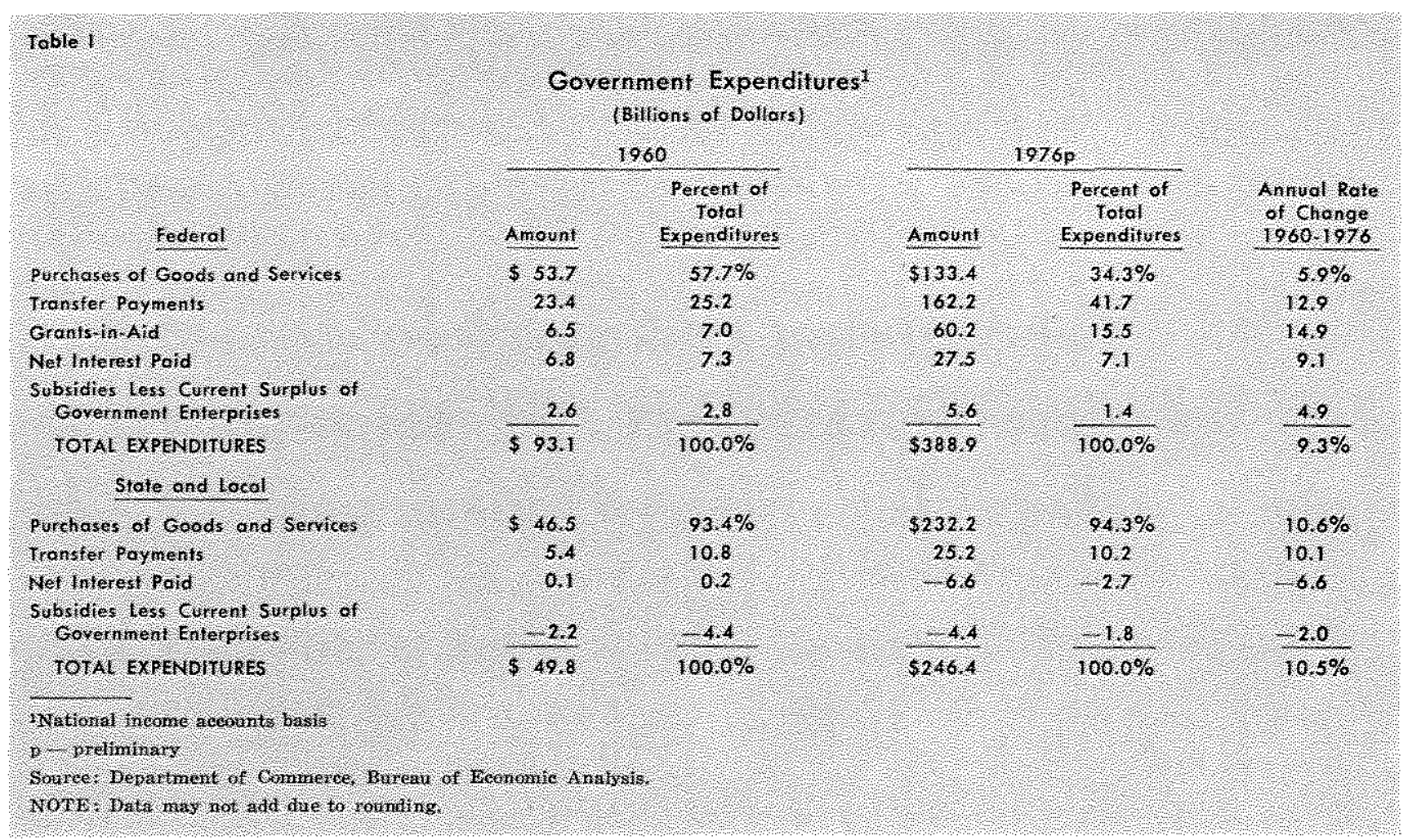

transfer payments represent government actions to redistribute income, and thereby spending decisions, from one sector of the economy to another. The Federal sector plays a more important role in these types of expenditures than do state and local governments. Transfer payments to individuals represent 10 percent of state and local expenditures, but account for 42 percent of Federal expenditures and currently are the largest category of Federal expenditure.

Grants-in-aid, which are counted as Federal expenditures but are receipts of state and local govemments, transfer resource-use decisions from the private sector to state and local governments by way of the Federal Government. Federal grants accounted for only 7 percent of Federal expenditures in 1960, compared to the current 16 percent. Of course, both of these types of transfers (to individuals and to other levels of government) frequently are accompanied by stipulations as to how these resources are to be used.

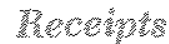

State and local receipts increased at an average annual rate of 10.9 percent from 1960 to 1976 , while Federal receipts have increased at an 8 percent average rate (Table II). Major sources of tax receipts for state and local governments currently include sales taxes (22.1 percent) and property taxes ( 22 percent).
Personal income taxes account for 10.2 percent of state and local receipts, while corporate income taxes produce 3.3 percent of total receipts. Contributions for social insurance, which include various employee retirement funds and contributions to workmen's compensation, represent another 6.5 percent of state and local receipts. The greatest change in the composition of state and local tax receipts from 1960 to 1976 has been the relative decline in receipts from property taxes ( 32.5 percent of total receipts in 1960 versus 22 percent in 1976) and an increase in income tax receipts (5 percent in 1960 versus 10.2 percent in 1976).

While these five taxes produce 64 percent of state and local receipts, approximately 91 percent of total Federal receipts are derived from only three sources: individual income taxes ( 42.3 percent), corporate income taxes ( 16.8 percent) and contributions for social insurance ( 32 percent). Thus, in general, state and local governments derive their revenues from a different group and a greater variety of taxes than does the Federal Government.

Since 1960 Federal grants to state and local governments have grown faster than every source of tax receipts except personal income taxes. Federal grants currently constitute 23.1 percent of total receipts at the state and local level, compared to 13 percent in 1960. Table III shows the current composition of 


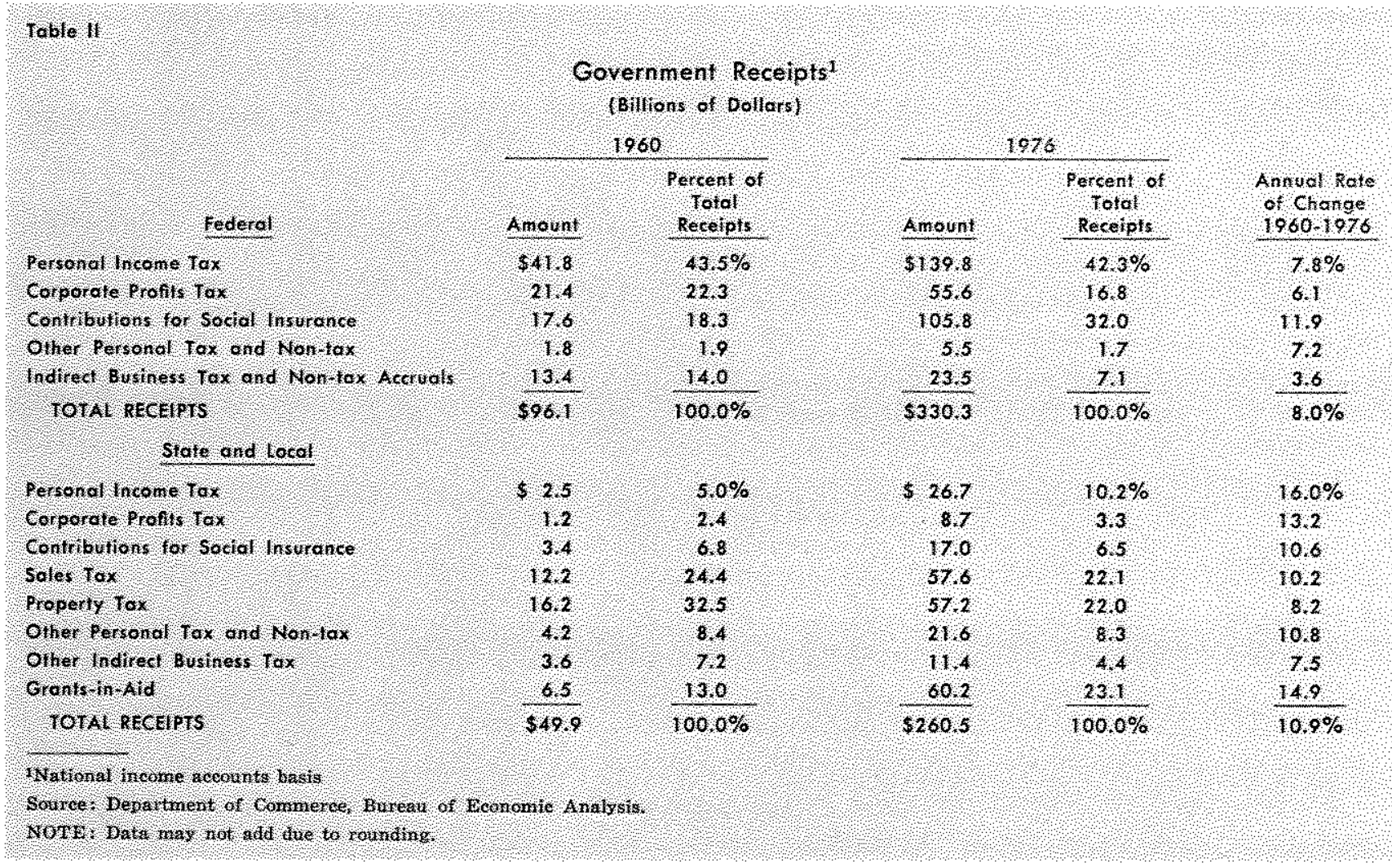

Federal grants, which include funds earmarked both for special purposes, such as highways and education, and general purpose funds, such as revenue sharing. Some grants require matching funds from the receiving government.

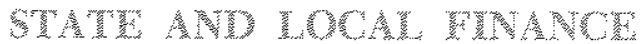

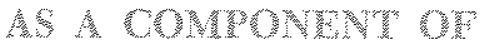

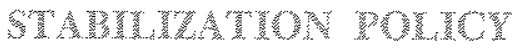

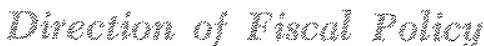

Given the differences in the growth and composition of state and local receipts and expenditures relative to those at the Federal level, the behavior of these items over the course of economic cycles is a factor which should be considered in discussions of government stabilization efforts. A useful measure of this behavior is the net change in state and local expenditures and receipts - that is, changes in budget surpluses and deficits. ${ }^{2}$ Appropriate fiscal policy, in the

\footnotetext{
2Studies using this approach include Robert W. Rafuse, Jr., "Cyclical Behavior of State-Local Finances" in Essays in Fiscal Federalism, Richard A. Musgrave, ed. (Washington: The Brookings Institution, 1965), pp. 63-121 and Ansel $M$. Sharp, "The Behavior of Selected State and Local Government Fiscal Variables During the phases of the Cycles 1949-1961," Proceedings, National Tax Association, 1965, pp. $599-613$.
}

view of analysts, requires movement away from surplus during recession (expenditure growth exceeding

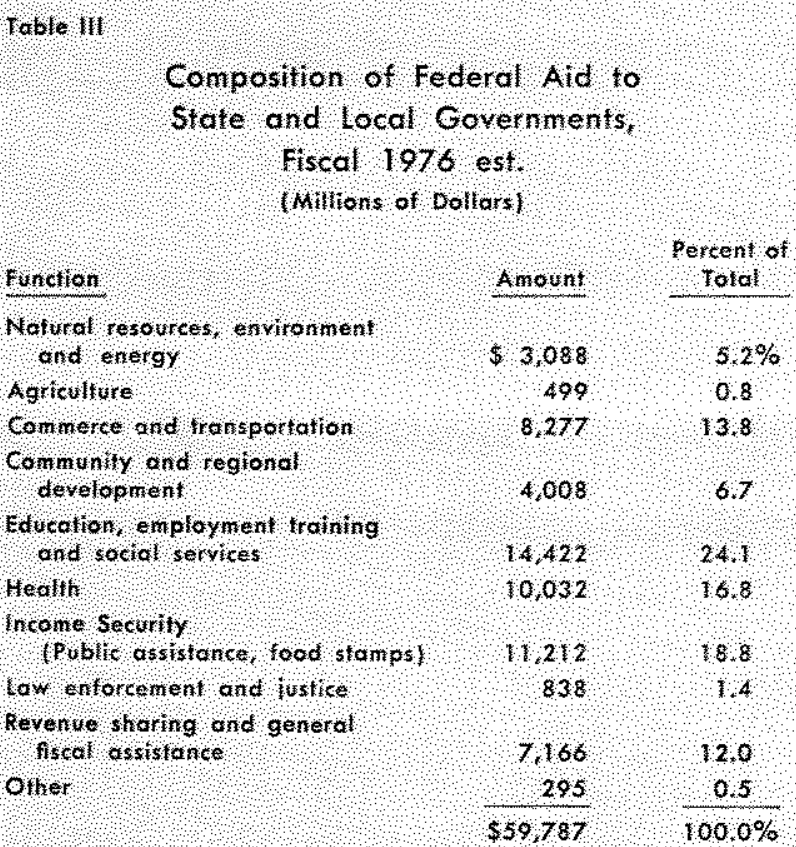

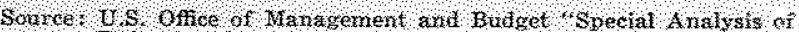

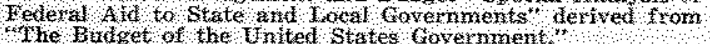

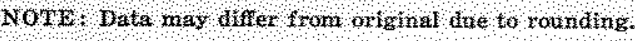


growth of receipts). ${ }^{3}$ Likewise, appropriate government fiscal policy during expansion would require movement toward surplus (growth of receipts in excess of expenditure growth).

In postwar business cycles, state and local expenditures have tended to increase relative to receipts during recessions (Table IV). On average, expenditures grew at a 12.7 percent rate during the five previous recessions, while receipts increased at an average 8.5 percent rate. In the most recent recession expenditures increased at a 12.9 percent rate, while receipts increased at a 10 percent rate. The net effect of these relative growth rates was to move state and local budgets away from surplus positions during recessions. This is the appropriate policy (fiscal stimulus espoused by fiscal activists, and such stimulus reinforces similar movements at the Federal level.

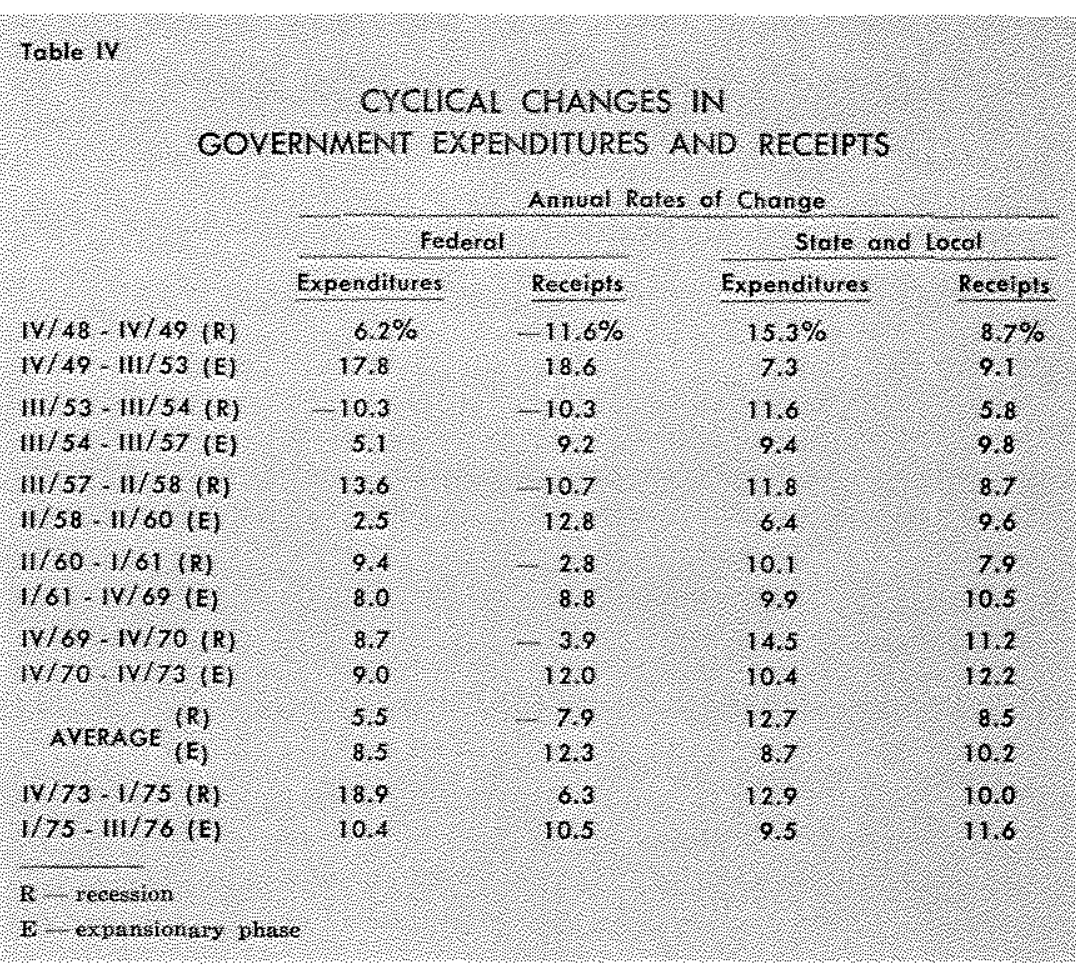

Over expansionary phases, state and local receipts have increased at a faster pace than expenditures, moving state and local budgets towards surplus positions. On average, receipts have increased over the course of previous economic expansions at a 10.2 percent rate, while expenditures have grown at an 8.7 percent rate. Since the first quarter of 1975 , the beginning of the current recovery, state and local receipts have increased at an 11.6 percent rate, compared to a 9.5 percent rate of increase of expenditures. Thus, in the current as well as in past expansions, state and local budgets have moved toward surplus, the movement prescribed by many fiscal policy proponents.

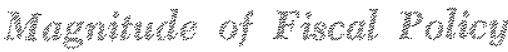

Although there remains some controversy concerning the nature of the effects, the impact of government stimulus or restraint on the level of economic activity depends not only on the direction of budget changes, but also on the magnitude of these changes. It is important to remember, however, that while changes in the Federal budget position may reflect deliberate actions to influence economic activity, the

\footnotetext{
3 For example, see Otto Eckstein, Public Finance, 3rd ed. (Englewood Clifts, New Jersey: Prentice-Hall, Inc., 1973), p. 121 .
}

state and local budget position is aggregated over 80,000 govermmental budgets. Changes in state and local budgets constitute an implicit fiseal policy which can be taken into account, but which would be difficult to coordinate with actions at the Federal level, especially given the different character of expenditures and receipts which was discussed above.

One method of measuring the degree of fiscal stimulus or restraint produced by governmental finances is by changes in the NIA budget surplus or deficit (see Chart).* Table $\mathrm{V}$ presents the dollar change from the previous year in the Federal and state and local budgets on an NIA basis. For example, changes in the Federal NIA budget between 1975 and 1976 produced about $\$ 13$ billion of fiscal restraint. State and local budgets accounted for an additional $\$ 7$ billion of restraint, or about a third of total government fiscal restraint.

Changes in the full employment budget can also be used to assess the degree of government fiscal impact on economic activity. The full employment budget concept was developed in an attempt to eliminate the automatic influences of economic fluctuations on the

4 For a discussion of various methods of calculating the impact of budgets on GNP, see Saul H. Hymans and J. Philip Wernette," "The Impact of the Federal Budget on Total Spending," Bustness Economics (September 1970), pp. 2934. 


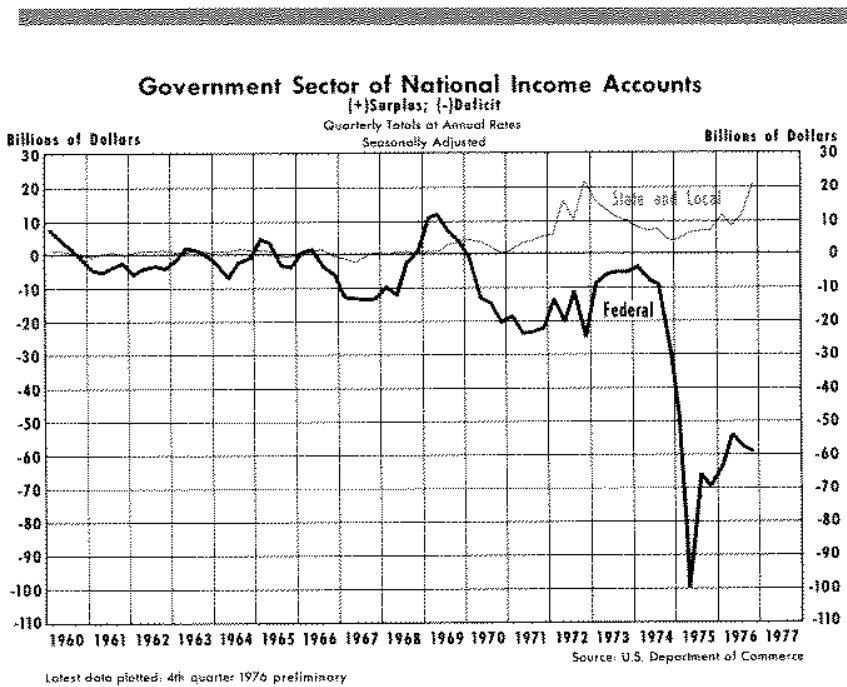

budget. For example, tax receipts generally decrease during an economic downturn, while expenditures for unemployment benefits at the Federal level increase. By eliminating these "passive" elements of the budget, more attention is focused on "active," or discretionary, changes in the budget. ${ }^{5}$ Realizing the implicit fiscal policies of state and local budgetary policies, the Council of Economic Advisers has attempted since 1974 to measure the full employment budget position of both the Federal and state and local governments. ${ }^{6}$ The combined impact of both budgets gives a more complete picture of the extent of government fiscal activity. Based on changes from the previous year, the 1976 Federal Government budget on a full employ ment basis exercised $\$ 2.2$ billion in restraint, while state and local full employment budgets contributed an even greater $\$ 3.1$ billion of restraint. ${ }^{\top}$ As the examples illustrate, whatever the ultimate impact of fiscal policy on the economy and however it is measured, an assessment of the degree of fiscal stimulus or restraint is incomplete without consideration of the state and local sector.

\footnotetext{
"See Keith M. Carlson, "Large Federal Budget Deficits: Perspective and Prospects," this Review (October 1976), pp. 2-7.

EEconomic Report of the President 1974, pp. 80-81. Recognition of the significance of state and local budget positions in the assessment of fiscal policy can be found in Donald $\mathrm{L}$. Raiff and Richard M. Young, "Budget Surpluses for State and Local Governments: Undercutting Uncle Sam's Fiscal Stance?" Business Review, Federal Reserve Bank of Philadelphia (March 1973) pp. 19-28; Nancy H. Teeters, "Current Problems in the Full Employment Concept" and Robert C. Vogel, "The Responsiveness of State and Local Receipts to Changes in Economic Activity: Extending the Concept of the Full Employment Budget" in Studies in Price Stability and Economic Growth, Paper Nos. 6 and 7, Joint Economic Committee, June 30, 1975, 94th Cong. 1st Sess.
}

${ }^{7}$ Economic Report of the President, 1977, p. 76.

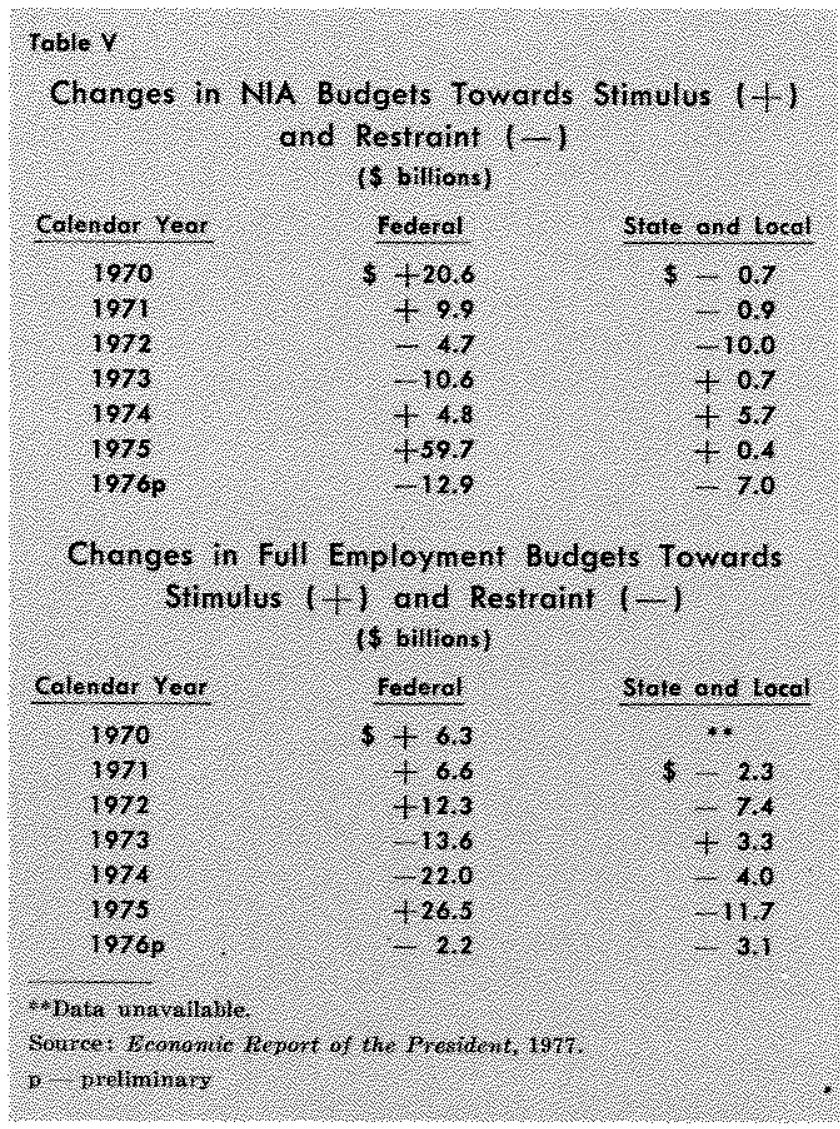

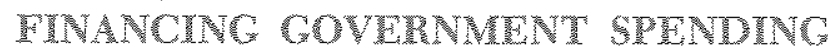

The way in which government spending is financed affects both the impact of the spending on aggregate economic activity and the perception of taxpayers concerning the costs of government programs. If the costs of government are affected by the method of financing, this can ultimately influence the size of government and, hence, the magnitude of fiscal effects on the economy.

\section{Methods of Financing}

Both Federal and state and local government spending can be financed directly by taxes or by borrowing from the public. In addition, Federal Government spending can be financed by borrowing indirectly from the Federal Reserve. The Federal Reserve buys Federal Government securities with newly created money. Thus, the Federal Reserve can, in fact, finance expenditures by printing new money or, more formally, "monetizing the debt." While the Federal Reserve does not operate in the market for state and local debt, these governments have the Federal Government, through grants-in-aid, as an additional source of revenue and thus, in an indirect manner, have ac- 
cess to all the methods of financing available to the Federal Government including debt monetization.

Trases .... Spending financed by tax revenue, whether at the Federal or state and local level, results in a direct transfer of resources from the private sector to the public sector. The costs of government spending financed by taxes are explicitly known to taxpayers. The imposition of taxes alters private consumption and investment decisions, and this will ultimately affect the composition, if not the level, of output and employment.

Borrowing frow the palde - When government spending is financed by borrowing from the public, control over resources is also transferred from the private sector to the public sector. The costs of government spending financed by borrowing from the public are less directly known to taxpayers than if the spending were financed by taxes. However, taxpayers will eventually become aware of the costs if the principal and interest are repaid through tax revenue.

Government borrowing represents an increased demand for credit. If there is no increase in the public's desire to supply credit (savings) or no offsetting decrease in private credit demand, the effect of the government borrowing will be to put upward pressure on interest rates. At higher interest rates some private borrowers will be crowded out of the market. ${ }^{8}$ Some state and local governments, which have restrictions as to the maximum interest rate at which they can borrow, will also be forced out of the market. Higher interest rates increase the cost of mortgages, consumer loans, and loans for capital investment. Again, private consumption and investment decisions will be altered. This will change the composition, if not the level, of output and employment.

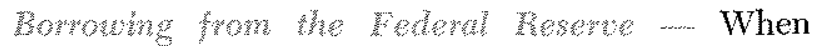
there is an upward movement in interest rates, there can be pressure on the Federal Reserve to resist such movements given current operating procedures. In the short run the Federal Reserve can ease pressure on interest rates by purchasing Federal debt. The Federal Reserve generally does not purchase Federal debt directly from the Treasury, but rather in the open market. By purchasing the debt the Federal Reserve increases reserves in the banking system and mitigates the initial upward pressures on interest rates. At the

see Roger W. Spencer and William P. Yohe, "The "Crowding Out' of Private Expenditures by Fiscal Policy Actions," this Retiew (October 1970), pp. 12-24 and Keith M. Carlson and Roger W. Spencer, "Crowding Out and Its Critics," this Review (December 1975), pp. 2-17. same time, this action increases the rate of monetary expansion which, over an extended period, leads to higher rates of inflation and eventually higher interest rates. Of course, the decision to monetize the debt has been at the discretion of the Federal Reserve.

The costs of financing government spending through monetary expansion are even less clearly discernable than financing through taxes and borrowing. While the costs of inflation are less apparent, they are no less real than the imposition of taxes or the costs of borrowing.

The ultimate monetary authority is at the Federal level. State and local governments do not have direct authority to create money and the Federal Reserve does not purchase state and local debt. Nevertheless, the initial source of upward pressure on interest rates may have been increased credit demands by either the Federal Government to finance Federal spending, by state and local governments to finance their spend. ing, or by the private sector to finance its spending. Thus, while state and local debt is not directly purchased by the Federal Reserve, it can be indirectly accommodated by Federal Reserve actions to hold down interest rates in the short run.

The combination of the more indirect access to money creating powers and certain legal restrictions on borrowing tend to make state and local governments operate under a tighter budget constraint than the Federal Govemment. This is evidenced by the fact that state and local government budgets in the aggregate have been in surplus on an NIA basis in 14 of the last 17 years, compared to only 4 surpluses incurred by the Federal Government over this period. Since expenditures are more likely to be financed by available receipts than by monetary expansion at the state and local level, taxpayers are more aware of the costs of state and local spending than the costs of Federal spending,

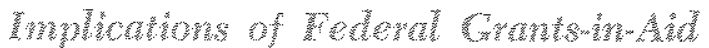

When state and local government spending is financed by Federal aid, the impact on economic activity depends on how this Federal spending is financed. The fact that spending in this instance is one step removed from paying for the programs makes the net benefit of the state and local government expenditures more difficult to assess. In particular it is more likely that the real costs of spending will be underestimated.

To the extent that Federal aid is financed by Federal taxes, resources are transferred from the private sector to the public sector. In this case it becomes a 


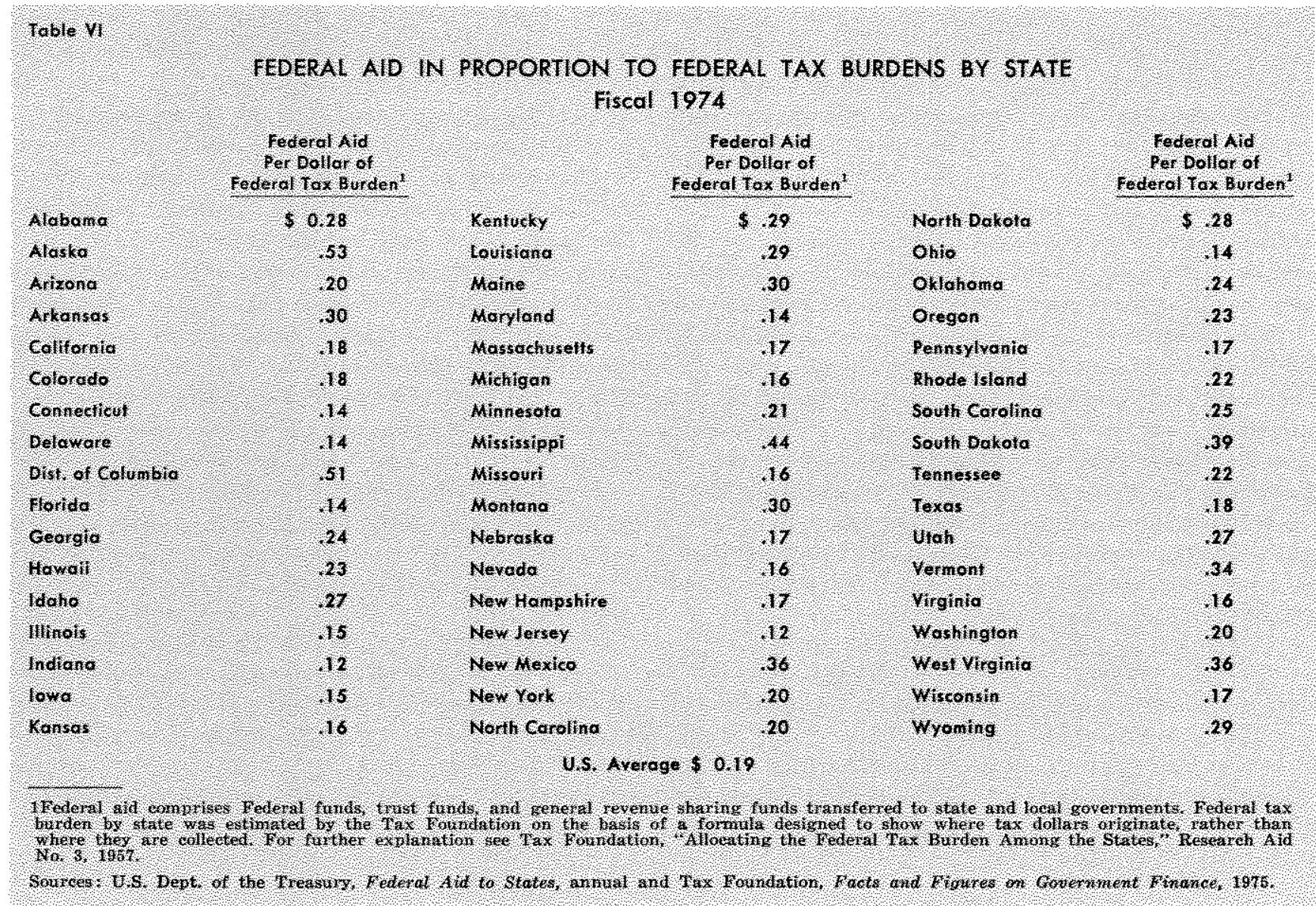

two-stage process; resources are first transferred to the Federal Government and then to state and local govermments. The costs of any particular state and local program are borne across the economy in proportion to taxpayers' Federal tax liabilities, rather than their state and local tax liabilities. Private spending and investment decisions will be altered, but in a manner corresponding to the impact of Federal taxes, rather than in a manner resulting from the same expenditures being financed by taxes at the state and local level. As Table VI indicates, rough estimates suggest that the Federal aid received by states does not correspond closely with the Federal tax burden of the people in the respective states. The average amount of Federal aid per dollar of Federal tax burden nationally is 19 cents. However, Federal aid ranges from 12 cents per dollar of Federal tax burden in Indiana and New Jersey to 53 cents per tax dollar in Alaska.

To the extent that Federal aid is financed by Federal borrowing from the public, resources are also transferred from the private sector to the public sector. Without compensating changes in the supply or other demands for credit, the Federal borrowing will put upward pressure on interest rates and alter private investment and consumption decisions.

If Federal aid is financed by borrowing from the Federal Reserve (monetization of the debt), then Federal aid to state and local governments is ultimately financed by increased monetary expansion and a faster rate of inflation in the future. Federal aid, in effect, gives state and local governments greater access to Federal powers of money creation. The costs of spending financed in this manner are not obvious. However, these costs take the form of a higher rate of inflation distributed over the entire economy.

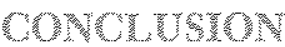

Although there is much concern about the increasing size of govermment, attention is usually focused on the Federal Government, whereas the state and local sector represents a larger portion of GNP and is grow. ing more rapidly. Likewise, the impact of fiscal policy on economic activity is generally centered on explicit Federal Government decisions. However, the spending and taxing decisions of state and local govern- 
ments, although operating under somewhat different circumstances than the Federal Government, do constitute an implicit fiscal policy.

The influence of state and local governments on economic activity depends both on the size of the stimulus or restraint reflected in budget changes and on the method in which spending is financed. The amount of fiscal restraint or stimulus reflected in state and local budgets in recent years has been of suffcient magnitude to merit consideration in conjunction with Federal fiscal policies. Likewise, examination of the ways in which state and local spending is financed shows that it can infuence economic activity in much the same way as Federal spending. In particular, state and local spending can be financed by monetary expansion, even though the ultimate monetary authority is at the Federal level. Although the Federal Reserve does not purchase state and local debt, tupward pressure on interest rates resulting from increases in state and local credit demands can lead to accommom dation by the Federal Reserve.

The increasing importance of Federal aid as a source of state and local revenue means that state and local governments have access to Federal sources of financing. The ability to spend at the state and local level with funds raised at the Federal level makes it more difficult to correctly determine the desired level of state and local government spending. The complete costs of state and local spending are not readily apparent and, therefore, more spending may take place than taxpayers would be willing to pay for if they were fully informed of the costs. To correctly assess the net benefit of state and local spending financed by Federal aid, it is important to be aware of the possible costs: higher taxes, higher interest rates, and/or a higher future rate of inflation.

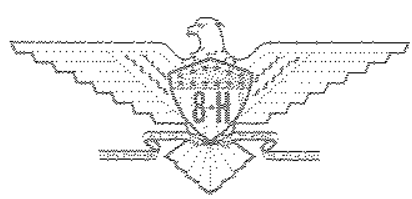

